\title{
Carcass characteristics and cuts of Santa Inês lambs fed different roughage proportions and fat source ${ }^{1}$
}

\author{
Iraides Ferreira Furusho Garcia², Amélia Katiane de Almeida², Tharcilla Isabella Rodrigues \\ Costa $^{2}$, Izac Leopoldino Júnior ${ }^{2}$, Julimar do Sacramento Ribeiro ${ }^{2}$, Fernando Antonio de Souza ${ }^{2}$ \\ 1 Financiado pela FAPEMIG (Fundação de Amparo a Pesquisa do Estado de Minas Gerais). \\ 2 Departamento de Zootecnia da Universidade Federal dos Vales do Jequitinhonha e Mucuri.
}

ABSTRACT - This work aimed at determining the influence of roughage proportions and fat source of the diet on characteristics of carcass and comercial cuts of lambs. It was used 24 non-castrated Santa Inês male lambs, ad libitum fed diet with two proportions of roughage (30 and $70 \%$ ) and fat (no fat, protected fat, and soybean) slaughtered at an avarage body weight of $35.4 \mathrm{~kg}$ ( $\pm 1.5 \mathrm{~kg}$ ). Animals fed $30 \%$ roughage diet showed the highest weights and carcass yields. The percentages of posterior arm and ham were higher in animals fed 30\% roughage with no addition of fat source. Total leg length and internal length were higher in animals fed $70 \%$ roughage diet while leg width was higher for those fed $30 \%$ roughage diet. Addition of fat source in diets with high percentage of concentrate can increase carcass yields. This effect is higher when protected fat is used regarded to whole soybean. Although diets do not have effect on most of these cuts, the effect on the ham confirms the influence of the diet on this noble cuts.

Key Words: nutrition, ovine meat, performance, protected fat, soy bean

\section{Características da carcaça e dos cortes de cordeiros Santa Inês alimentados com rações com diferentes proporções de volumoso e fontes de gordura}

RESUMO - Objetivou-se determinar a influência da proporção volumoso e da fonte de gordura da dieta sobre as características de carcaça e os cortes comerciais de cordeiros. Utilizaram-se 24 cordeiros Santa Inês machos não-castrados, recebendo, à vontade, dieta com duas proporções de volumoso (30 e 70\%) e de gordura (sem gordura, gordura protegida e grão de soja) e abatidos com peso corporal médio de $35,4 \mathrm{~kg}$ ( $\pm 1,5 \mathrm{~kg}$ ). Os animais alimentados com dietas com $30 \%$ de volumoso apresentaram os maiores pesos e rendimentos de carcaça. As porcentagens de braço posterior e pernil foram maiores nos animais que receberam a dieta com $30 \%$ de volumoso sem adição de fonte de gordura. O comprimento total de perna e o comprimento interno foram maiores nos animais que receberam a dieta com $70 \%$ de volumoso, enquanto a largura de perna foi maior naqueles alimentados com a dieta com 30\% de volumoso. A adição de fonte de gordura em dietas com alta porcentagem de concentrado pode aumentar os rendimentos de carcaça. Esse efeito é maior quando utilizada gordura protegida em relação ao grão de soja integral. Apesar de as dietas não terem efeito na maioria dos cortes, o efeito sobre o pernil confirma a influência da dieta sobre esse corte nobre.

Palavras-chave: carne ovina, desempenho, gordura protegida, grão de soja, nutrição

\section{Introduction}

Nowadays, the main purpose of the Brazilian sheep breeding is meat production. However, the quality of the product is still an obstacle to ovine meat conquers a stable market. The nutritional management of the animal can interfere on the quality of this meat and on other factors such as weight and carcass yield and on retail cuts, which are extremely important factors to measure the capacity of the animal to produce meat (Alves et al., 2003). The carcasses can be marketed as a whole or as cuts. The individualized cuts associated to the product presentation are important in the commercialization because they provide the obtaition of differentiated prices allowing rational use, avoiding waste (Silva Sobrinho \& Silva, 2000), and the yield of these cuts is an important index for quality evaluation. The importance of evaluation of the carcass measures is that according to El Karin et al., (1988), when combined with the carcass weight, they satisfactorily predict composition in muscle, fat and bone. According to Garcia et al. (2003), the studies on carcasses have the purpose of evaluating subjective and objective parameters, since they are related 
with qualitative and quantitative aspects of the same. In this context, the area of loin eye is considered a measure that represents the amount and distribution of the muscular masses (Bonifacino et al., 1979).

According to Bendahan (2008), the management in feedlot is the best in order to reach larger productivity, and factors as rate of completion, food conversion, quality of the available animals, price and quality of food, consuming market of quality meat should be taken into account for the producer achieves a better economic return in the activity. The inclusion or not of fat sources in diet can commit the animal performance, because polyunsaturated fatty acids of long free chain are potentially poisonous to rumen microorganisms, damaging mainly the diets with high fiber proportions (Gibb et al., 2005). The objective of the present work was to evaluate carcass characteristics and retail cuts of Santa Inês lambs, fed in feedlots with diets containing or not different fat sources, whole soybean and protected fat.

\section{Material and Methods}

The experiment was carried out in Fazenda Experimental do Moura, Curvelo-MG, Setor de Ovinos of the Departamento de Zootecnia, of Universidade Federal dos Vales do
Jequitinhonha e Mucuri. It was evaluated 24 Santa-Inês male lambs, weaned at $10 \mathrm{~kg}$ of average body weight. After weaning, they were kept in groups in feedlots until reaching $15 \mathrm{~kg}$ of body weight at an average age of 121 days $( \pm 13.06$ days), when they were sent to the individual feedlot and randomly distributed to each one of the treatments. The following experimental diets were given once a day ad libitum: two roughage: concentrated proportions (70:30 and 30:70\%, respectively). Tifton hay (Cynodom sp) was used as roughage, and the concentrate with or without inclusion of fat source consisted of ground whole soybean or protected fat - calcium soaps (Table 1). The presented food and leftovers were daily weighed, fixing $20 \%$ of leftovers. From the beginning of the confinement, the lambs were weighed weekly for monitoring body weight gain until they reached slaughter weight $(35.4 \mathrm{~kg})$.

The diets presented an average of $15.11 \%$ for crude protein, and 2,399.11 kcal/kg of dry matter for metabolizable energy, calculated according to NRC (1985) for lambs with weight gains of $295 \mathrm{~g} /$ day.

The animals were slaughtered after aproximately 14 hours of fasting of solids. They were eviscerated and later, the carcass were weighed and taken for cooling in a cold storage chamber (from 2 to $4^{\circ} \mathrm{C}$ ) for 24 hours, when it was removed and the weight of cold carcass was taken. The

Table 1 - Composition of ingredients and nutrients of experimental diets

\begin{tabular}{|c|c|c|c|c|c|c|}
\hline & \multicolumn{6}{|c|}{ Diets - Roughage:concentrated (\%) } \\
\hline & $30: 70$ & $30: 70$ & $30: 70$ & $70: 30$ & $70: 30$ & $70: 30$ \\
\hline & \multicolumn{6}{|c|}{ Fat source } \\
\hline & Without addition & Protected fat & Integral soy & Without addition & Protected fat & Integral soy \\
\hline \multicolumn{7}{|l|}{ Ingredient (\%) } \\
\hline Tifton hay & 30.00 & 30.00 & 30.00 & 70.00 & 70.00 & 70.00 \\
\hline Crushed soybean & 51.60 & 42.00 & 46.10 & 18.20 & 2.70 & 6.50 \\
\hline Soy bran & 16.50 & 22.00 & 0.00 & 9.50 & 21.00 & 0.00 \\
\hline Protected $\mathrm{fat}^{4}$ & 0.00 & 5.00 & 0.00 & 0.00 & 5.00 & 0.00 \\
\hline Integral soybean & 0.00 & 0.00 & 22.00 & 0.00 & 0.00 & 22.00 \\
\hline Limestone & 0.90 & 0.00 & 0.90 & 0.40 & 0.00 & 0.50 \\
\hline Urea & 0.00 & 0.00 & 0.00 & 0.80 & 0.00 & 0.00 \\
\hline Phosphoric acid & 0.00 & 0.00 & 0.00 & 0.10 & 0.30 & 0.00 \\
\hline Mineral/vitaminic premix & 1.00 & 1.00 & 1.00 & 1.00 & 1.00 & 1.00 \\
\hline \multicolumn{7}{|l|}{ Nutrient } \\
\hline Crude protein $(\%)^{1}$ & 12.74 & 11.93 & 1085 & 8.61 & 12.83 & 13.92 \\
\hline Neutral detergent fiber $(\%)^{2}$ & 51.32 & 57.73 & 56.37 & 43.67 & 44.55 & 38.02 \\
\hline Acid detergent fiber $(\%)^{2}$ & 14.51 & 15.91 & 15.30 & 30.22 & 28.46 & 26.23 \\
\hline Cell content $(\%)^{2}$ & 48.68 & 42.27 & 43.63 & 56.33 & 55.45 & 61.98 \\
\hline Hemicellulose $(\%)^{2}$ & 36.82 & 41.83 & 41.06 & 13.45 & 16.08 & 11.79 \\
\hline Ashs $(\%)^{1}$ & 4.76 & 5.22 & 4.80 & 6.18 & 6.82 & 6.50 \\
\hline EM $(\mathrm{kcal} / \mathrm{kg})^{3}$ & 2.56 & 2.78 & 2.61 & 2.06 & 2.27 & 2.12 \\
\hline Ethereal extract $(\%)^{3}$ & 2.89 & 6.74 & 6.57 & 2.45 & 6.19 & 6.03 \\
\hline Calcium $(\%)^{3}$ & 0.51 & 0.63 & 0.52 & 0.48 & 0.79 & 0.54 \\
\hline Phosphorus $(\%)^{3}$ & 0.28 & 0.29 & 0.29 & 0.24 & 0.32 & 0.26 \\
\hline
\end{tabular}

${ }^{1}$ Quantified according to AOAC methodology (1990). ${ }^{2}$ Quantified according to Silva methodology (1981); ${ }^{3}$ Calculated according to composition of ingredients on NRC Table (1985); ${ }^{4}$ Calcium soaps - composition presented by the supplying company of the product. 
weight of hot and cold carcass was used in relation to slaughter weight to calculate their yield. It was also calculated the real yield obtained from the empty weight of each animal, in other words, heavy digestive contents discounted after evisceration.

After the carcass removal from the cold storage chamber, the following carcass measures were taken according to Fisher \& Boer (1994): total length (distance from the base of the tail to the base of the neck); subcutaneous fat (taken from the $12^{\text {th }}$ to the $13^{\text {th }}$ rib); croup width (maximum width between the trochanters of both femurs); croup perimeter (perimeter of this area, referenced by the trochanters of both femurs). Next, the carcass was longitudinally divided into two equal parts. Internal length (maximum distance between previous board of the ischium-pubic symphysis and previous board of the 1 st $\mathrm{rib}$ ), leg length (distance between fibula and previous board of tarsal metatarsal articulation), and thorax depth (maximum width between breastbone and back) were measured in the left half carcarss according to Fisher \& Boer (1994). The area of longissimus dorsi (loin eye) muscle was measured through transparent standard form squared ( $1 \mathrm{~cm}^{2} /$ cell), adapted from Cunha et al. (2001) and thickness of subcutaneous fat was measured in the cut made between the $12^{\text {th }}$ and $13^{\text {th }}$ ribs.

After the removal of the tail, kidneys and perirenal and cavity fats, the left half carcass was subdivided into the following retail cuts: leg, loin, shoulder, chop, rib/belly, previous arm, subsequent arm and neck, as described by Furusho-Garcia et al. (2004), and they were weighed for calculation of proportions ( $\%$ in relation to cold carcass weight).

The data were analyzed in SAS program (SAS, 1991). The experimental design was entirely randomized in a $2 \times 3$ factorial outline (two roughage: concentrated proportions and three fat sources), with four repetitions for diet. The averages were compared by Tukey's test at 5\% of significance.

\section{Results and Discussion}

The animals fed $30 \%$ of roughage diet presented greater weights and yields of hot and cold carcass when compared to individuals fed larger roughage proportion, a result that was already provided once diets with larger concentrate proportion usually make available more metabolizable energy which provides larger muscular mass growth and adipose tissue that compose the carcass (Table 2).

However, there was no effect $(\mathrm{P}>0.05)$ of roughage proportion under the real yield of cold carcass, what can be explained by a significant difference in weight and proportion (in relation to slaughter weight) of digesting content among animals consuming different diets, in which those that consumed diets with $70 \%$ of roughage presented content weight of $6.80 \mathrm{~kg}$ (19.22\%) compared to $5.02 \mathrm{~kg}$ (14.17\%) of those that consumed diets with $30 \%$ of roughage.

For both of hot and cold carcass weights, their yield and slaughtered weight showed inherence to addition of fat source in the diets of Santa Inês lambs corroborating with the results found by Urano et al. (2006), who working with

Table 2 - Means of the percentages (\%) and weights (kg) of retail cuts of Santa Inês lambs in function of roughage proportion and fat source *

\begin{tabular}{|c|c|c|c|c|c|c|}
\hline \multirow[b]{2}{*}{ Fat source } & \multicolumn{6}{|c|}{ Roughage proportion: concentrated } \\
\hline & $30: 70$ & $70: 30$ & Mean & $30: 70$ & $70: 30$ & Mean \\
\hline & \multicolumn{3}{|c|}{ Hot carcass weight } & \multicolumn{3}{|c|}{ Cold carcass weight } \\
\hline Without fat & 16.23 & 16.00 & $16.11 \mathrm{a}$ & 15.46 & 15.48 & $15.47 \mathrm{a}$ \\
\hline With protected fat & 17.49 & 15.60 & $16.54 \mathrm{a}$ & 16.93 & 15.40 & $16.16 \mathrm{a}$ \\
\hline With integral soybean & 17.23 & 15.45 & $16.34 \mathrm{a}$ & 16.88 & 14.93 & $15.90 \mathrm{a}$ \\
\hline \multirow[t]{2}{*}{ Mean } & $16.98 \mathrm{~A}$ & $15.68 \mathrm{~B}$ & 16.33 & $16.43 \mathrm{~A}$ & $15.27 \mathrm{~B}$ & 15.84 \\
\hline & \multicolumn{3}{|c|}{ Hot carcass yield } & \multicolumn{3}{|c|}{ Cold carcass yield } \\
\hline Without fat & 46.04 & 44.77 & $45.41 \mathrm{a}$ & 43.94 & 43.29 & $43.62 \mathrm{a}$ \\
\hline With protected fat & 50.60 & 43.96 & $47.28 \mathrm{a}$ & 48.98 & 43.38 & $46.18 \mathrm{a}$ \\
\hline With integral soybean & 47.49 & 44.31 & $45.90 \mathrm{a}$ & 46.52 & 42.82 & $44.67 a$ \\
\hline \multirow[t]{2}{*}{ Mean } & $48.05 \mathrm{~A}$ & $44.35 B$ & 46.20 & $46.48^{\mathrm{A}}$ & $43.17 \mathrm{~B}$ & 44.82 \\
\hline & \multicolumn{3}{|c|}{ Cold carcass true yield } & \multicolumn{3}{|c|}{ Slaughter weight } \\
\hline Without fat & 51.38 & 53.57 & $52.48 \mathrm{a}$ & 37.10 & 37.38 & $37.36 a$ \\
\hline With protected fat & 55.58 & 54.47 & $55.02 \mathrm{a}$ & 36.56 & 38.05 & $37.31 \mathrm{a}$ \\
\hline With integral soybean & 55.48 & 52.48 & $53.98 a$ & 37.33 & 37.40 & $37.24 \mathrm{a}$ \\
\hline Mean & $54.15 \mathrm{~A}$ & $53.50 \mathrm{~A}$ & 53.83 & 36.99A & $37.61 \mathrm{~A}$ & 37.30 \\
\hline
\end{tabular}

* Means followed by different letters, capital letter in lines and small letters in columns, differ $\mathrm{P}<0,05$ by Tukey’s test, comparing roughage or fat source, or differ by t test when the interaction was significant. 
Santa Inês ovines fed different levels of soybean $(0,7,14$, $21 \%$ ) did not find differences among diets for hot and cold carcass yield, whose observed averages were 48.9 and $47.7 \%$, respectively.

Significant differences were not observed $(\mathrm{P}>0.05)$ for carcass length, leg length, croup width, croup circumference and subcutaneous fat regardless to the addition of fat source and roughage proportions adopted in this study.

Considering the total leg length and internal length, it was observed that the group of animals that received diet containing $30 \%$ of roughage presented lower values for these measures, the ones which were not influenced by the addition of fat source. When the leg width was evaluated, it was observed that its measure $(10.17 \mathrm{~cm})$ was higher for lambs fed 30\% roughage compared with animals that received $70 \%$ of hay $(9.40 \mathrm{~cm})$. These results provide an indicative that carcass of lambs that receive smaller roughage proportion in diet present larger compactness of the leg, provided by the largest energy intake of diets composed by ingredients with better advantages, mainly in rumen, favoring higher muscular mass growth concerning to bone tissue.

The loin eye area presented significant interaction $(\mathrm{P}<0.05)$ between the fat source and roughage proportion of diet, and there was no significant difference in diets without addition of independent fat source of roughage proportion. When fat was added into the diet, it was verified that the protected fat provided larger loin eye area (2463 $\mathrm{mm}^{2}$ ) in diet with smaller roughage:concentrated relationship whereas the addition of soybean as fat source increased loin eye area in the diet with $70 \%$ of roughage. That result could be explained by some interaction between the diet ingredients after the addition of different fat sources. The inclusion of fat source in diet with smaller roughage:concentrate relationship increases its energy content more, providing animal tissue development. However, for diets with greater roughage:concentrate relationship, despite of elevating the energy density, the fat reduces the forage digestibility, which did not happen when soybean was used. However, when evaluating the average results for loin eye area obtained by ultrasound scanning before slaughter, it was observed that there were no differences among diets.

When evaluating the neck weight of animals that did not receive fat source, it was larger $(\mathrm{P}<0.05)$ for higher roughage proportion, with no differences in the percentage of this cut. With the use of protected fat, much weight as neck percentage in relation to cold carcass was larger in $30 \%$ roughage diets. The results indicate that this cut is markedly influenced by nutritional management maybe because this cut presents high fat proportion, a tissue that is easily affected by the nutrients.

The results showed that the rib/belly was influenced $(\mathrm{P}<0.05)$ by the addition of fat source in diet, but not by the roughage proportion, and the use of protected fat promoted larger weight and cut percentage when compared to animals that received soybean as fat source.

For the ham, which is a noble cut, the weight was smaller in lambs that received diets containing larger roughage tenor, while the addition of fat source did not influence this cut. However, the percentage of this cut in relation to cold carcass presented interaction between fat source and roughage proportion, and, in diets without fat source, the ham weight was larger for $30 \%$ of roughage. There was no variation ( $\mathrm{P}>0.05$ ) between the relationship roughage:concentrated when fat source was used, regardless to the source. For animals that received larger proportions of concentrate and did not receive fat sources, they presented a higher ham proportion. The results are in disagreement with Yamamoto et al. (2004) who evaluated

Table 3 - Measurements averages of carcasses $(\mathrm{cm})$ of Santa Inês ovines in function of the roughage proportion and fat source *

\begin{tabular}{|c|c|c|c|c|c|}
\hline \multirow[t]{2}{*}{ Treatments** } & \multicolumn{2}{|c|}{ Roughage:concentrate } & \multicolumn{3}{|c|}{ Fat source } \\
\hline & $30: 70$ & $70: 30$ & Without fat & $\begin{array}{l}\text { With protected } \\
\text { fat }\end{array}$ & $\begin{array}{c}\text { With whole } \\
\text { soy bean }\end{array}$ \\
\hline Carcass length (cm) & $51.94 \mathrm{~A}$ & $50.81 \mathrm{~A}$ & $52.56 a$ & $51.00 \mathrm{a}$ & $50.56 a$ \\
\hline Internal length (cm) & $62.74 \mathrm{~B}$ & $65.94 \mathrm{~A}$ & $64.25 a$ & $63.26 a$ & $65.51 \mathrm{a}$ \\
\hline Thorax depth (cm) & $27.21 \mathrm{~A}$ & $27.45 \mathrm{~A}$ & $26.55 b$ & $27.47 \mathrm{ab}$ & $27.96 a$ \\
\hline Leg length (cm) & $25.37 \mathrm{~A}$ & $25.63 \mathrm{~A}$ & $25.01 \mathrm{a}$ & $25.64 \mathrm{a}$ & $25.86 a$ \\
\hline Croup width $(\mathrm{cm})$ & $20.47 \mathrm{~A}$ & $21.18 \mathrm{~A}$ & $20.45 a$ & $21.30 \mathrm{a}$ & $20.74 a$ \\
\hline Total leg length (cm) & $40.42 \mathrm{~B}$ & $45.03 \mathrm{~A}$ & $41.96 \mathrm{a}$ & $42.97 a$ & $43.24 \mathrm{a}$ \\
\hline Leg widhth $(\mathrm{cm})$ & $10.17 \mathrm{a}$ & $9.40 \mathrm{~B}$ & $10.17 \mathrm{~A}$ & $9.80 \mathrm{a}$ & $9.27 \mathrm{a}$ \\
\hline Croup circumference $(\mathrm{cm})$ & $59.67 \mathrm{~A}$ & $59.73 \mathrm{~A}$ & $59.75 a$ & $59.22 \mathrm{a}$ & $60.12 \mathrm{a}$ \\
\hline Subcutaneous fat $(\mathrm{cm})$ & $2.54 \mathrm{~A}$ & $3.03 \mathrm{~A}$ & $3.01 \mathrm{a}$ & $2.45 \mathrm{a}$ & $2.90 \mathrm{a}$ \\
\hline Loin eye are by ultrasound $\left(\mathrm{mm}^{2}\right)$ & $891 \mathrm{~A}$ & $842 \mathrm{~A}$ & $896 a$ & $859 a$ & $845 a$ \\
\hline
\end{tabular}

* Means followed by different letters, capital letters or small letters in columns, differ by Tukey test, $(\mathrm{P}<0.05)$ for roughage: concentrated and fat source, respectively.** 
Table 4 - Measurement of the loin eye area of Santa Inês ovines in function of roughage proportion and fat source*

\begin{tabular}{lccc}
\hline \multicolumn{4}{c}{ Roughage } \\
\hline Fat source & $30: 70$ & $70: 30$ & Mean \\
\hline Without fat & $1857 \mathrm{Aa}$ & $1677 \mathrm{Ab}$ & 1767 \\
With protected fat & $2463 \mathrm{Aa}$ & $1360 \mathrm{Bb}$ & 1911 \\
With integral soybean & $1820 \mathrm{Ba}$ & $2766 \mathrm{Aa}$ & 2293 \\
Mean & 2046 & 1934 & 1990 \\
\hline
\end{tabular}

* Means followed by different letters, capital letters in lines and small letters in columns, differ by t test $(\mathrm{P}<0.05)$. the inclusion of fat sources (soybean oil, canola and linseed) in rations for Santa Inês purebreed lambs and Santa Inês x Dorset crossbreed, slaughtered at $30 \mathrm{~kg}$ of body weight, at an average age of 150 days, and differences were not observed for leg yield.

For the shoulder, carré, loin and anterior arm, there was no influence of diets on their weights and proportions. These results corroborate with Urano et al. (2006) who

Table 5 - Means of percentages (\%) and weights (kg) of retail cuts of Santa Inês lambs in function of roughage proportion and fat source

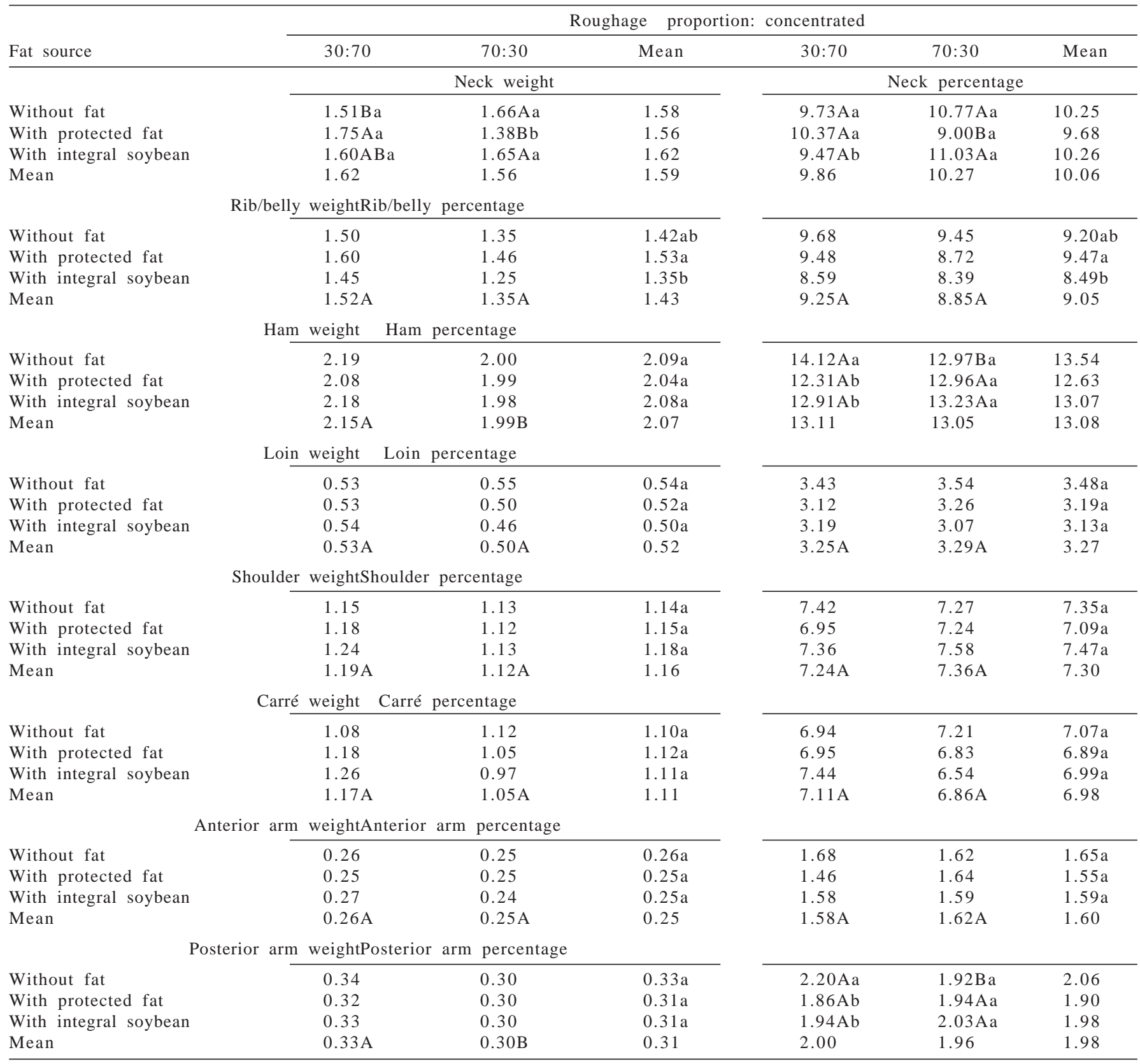

${ }^{1}$ Means followed by different letters, capital letter in lines and small letters in columns, differ among themselves by Tukey's test, $\mathrm{P}<(0.05)$, in means comparing roughage or fat source, or differ between themselves by $t$ test when the interaction was significant. 
evaluated the performance and carcass characteristics of confined lambs fed soybeans in growing levels $(0,7,14$, $21 \%$ ) and did not find difference among diets in the yield of retail cuts of Santa Inês lambs; and with Yamamoto et al. (2004) who did not observe difference in the yield of loin and shoulder.

Although the weights of cuts differed according to the diet (Table 5), in many cases yield did not differ significantly. This tendency can be explained by the law of harmony anatomical described by Boccard \& Dumont (1960), because in agreement with these authors, carcasses with similar weights and amounts of fat means that all body areas are in similar proportions, whatever the genotype frame is.

\section{Conclusions}

The yield and carcass weights of Santa Inês lamb reared in feedlot decreases when the roughage proportion goes from 30 to $70 \%$, but the same ones are not affected by the use of protected fat or whole soybean as fat source. The leg, a noble cut, present in higher proportion in carcass of lambs that are fed diets without fat source and with larger concentrate proportion.

\section{References}

ALVES, K.S.; CARVALHO, F.F.R.; FERREIRA, M.A. et al. Níveis de energia em dietas para ovinos Santa Inês: características de carcaça e constituintes corporais. Revista Brasileira Zootecnia, v.32, n.6, p.1927-1936, 2003.

ASSOCIATION OF OFFICIAL ANALYTICAL CHEMISTS - AOAC. Official methods of analysis. 15.ed. Arlington, 1990. v.1. $1117 p$.

BENDAHAN, A.B. [2008] Confinamento de cordeiros: uma alternativa na ovinocultura. Disponível em: <http:// www.agroline.com.br/ artigos/artigo.php?id=304>. Acesso em: $11 / 3 / 2008$.

BOCCARD, R.; DUMONT, B.L. Etude de la production de la viande chez les ovins. II. Variation de l'importance relative des differentes régions corporelles de l'agneaus de boucherie. Annales de Zootechnie, v.9, n.4, p.355-365, 1960.

BONIFACINO, L.; KREMER, R.; ORLANDO, D. et al. Estudio comparativo de corderos Corriedale y Corriedale por Texel. Pesos al nascer, ganancias diarias y caracteristicas de la carcaça. Revista Veterinária, v.70, p.63-71, 1979.

CUNHA, E.A.; BUENO, M.S.; SANTOS, L.E. et al. Desempenho e características de carcaça de cordeiros Suffolk alimentados com diferentes volumosos. Ciência Rural, v.31, n.4, p.671-676, 2001.

EL KARIN, A.I.A.; OWEN, J.B.; WHITAKER, C.J. Measurement on slaughter weight, side weight, carcass joints and their association with carcass composition of two types of Sudan Desert sheep. Journal of Agricultural Science, v.110, n.1, p.65-69, 1988.

FISHER, A.V.; BOER, H. The EAAP standard method of sheep carcass assessment. Carcass measurements ans dissection procedures. Report of the EAAP Working Group on Carcass Evaluation, in cooperation with the CIHEAM, Agronomic Institute Mediterraneo of Zaragoza and the CEC Directorate General for Agriculture in Brussels. Livestock Production Science, v.38, n.2, p.149-159, 1994.

FURUSHO-GARCIA, I.F.; PEREZ, J.R.O.; BONAGURIO, S. et al. Desempenho de cordeiros Santa Inês puros e cruzas Santa Inês com Ile de France e Bergamácia. Revista Brasileira de Zootecnia, v.33, n.6, p.1591-1603, 2004.

GARCiA, C.A.; MONTEIRO, A.L.G.; COSTA, C. et al. Medidas objetivas e composição tecidual da carcaça de cordeiros alimentados com diferentes níveis de energia em creep feeding. Revista Brasileira de Zootecnia, v.32, n.6, p.1380-1390, 2003

GIBB, D.J.; SHAH, M.A.; MIR, P.S. et al. Effect of full-fat hemp seed on performance and tissue fatty acids of feedlot cattle. Canadian Journal of Animal Science, v.85, p.223-230, 2005.

NATIONAL RESEARCH COUNCIL - NRC. Nutrient requirements of sheep. 6.ed. Washington, D.C.: NAS, 1985. 99p.

STATISTICAL ANALYSIS SYSTEM - SAS. SAS/STAT: user's guide version 6, 4.ed. Cary: 1991. 956p.

SILVA, S.S. Análise de alimentos (métodos químicos e biológicos). 2.ed. Viçosa, MG: UFV, 1981. 166p.

SILVA SOBRINHO, A.G.; SILVA, A.M.A. Produção de carne ovina Parte II. Artigo técnico. Revista Nacional da Carne, v.286, p.30-36, 2000.

URANO, F.S.; PIRES, A.V.; SUSIN, I. et al. Desempenho e características da carcaça de cordeiros confinados alimentados com grãos de soja Pesquisa Agropecuária Brasileira, v.41, n.10, p.1525-1530, 2006.

YAMAMOTO, S.M.; MACEDO, F.A.F.; MEXIA, A.A. et al. Rendimentos dos cortes e não componentes das carcaças de cordeiros terminados com dietas contendo diferentes fontes de óleo vegetal. Ciência Rural, v.34, n.6, p.1909-1913, 2004. 